\title{
Dimensi Metrik Kuat Lokal Graf Hasil Operasi Kali Kartesian
}

\author{
Nurma Ariska Sutardji ${ }^{1}$, Liliek Susilowati ${ }^{2, *}$ \& Utami Dyah Purwati ${ }^{3}$ \\ ${ }^{1,2,3}$ Departemen Matematika, Fakultas Sains dan Teknologi Universitas Airlangga
}

*Corresponding author: liliek-s@fst.unair.ac.id

\begin{abstract}
The strong local metric dimension is the development result of a strong metric dimension study, one of the study topics in graph theory. Some of graphs that have been discovered about strong local metric dimension are path graph, star graph, complete graph, cycle graphs, and the result corona product graph. In the previous study have been built about strong local metric dimensions of corona product graph. The purpose of this research is to determine the strong local metric dimension of cartesian product graph between any connected graph $\boldsymbol{G}$ and $\boldsymbol{H}$, denoted by $\operatorname{dim}_{\mathrm{sl}}(\boldsymbol{G} \times \boldsymbol{H})$. In this research, local metric dimension of $\boldsymbol{G} \times \boldsymbol{H}$ is influenced by local strong metric dimension of graph $\boldsymbol{G}$ and local strong metric dimension of graph $\boldsymbol{H}$. Graph $\boldsymbol{G}$ and graph $\boldsymbol{H}$ has at least two order.
\end{abstract}

Keywords: local strong metric dimension, cartesian product, bipartite graph, complete graph, cycle graph.

\section{Pendahuluan}

Konsep teori graf pertama kali dikenalkan oleh Leonhard Euler, seorang matematikawan asal Swiss yang berhasil menemukan solusi terhadap suatu permasalahan jembatan yang ada pada kota Konigsberg. Euler memodelkan permasalahan tersebut dalam bentuk graf, yaitu titik sebagai daratan dan sisi sebagai jembatan yang menghubungkan dua titik [1]. Teori graf dikenal sebagai teori yang dapat memodelkan setiap permasalahan menjadi bentuk titik dan garis. Pengaplikasian ilmu Teori Graf dalam kehidupan sehari-hari mencakup banyak hal antara lain yaitu mencari rute tercepat dari suatu lokasi ke lokasi lain dan menentukan rute perjalanan disuatu tempat wisata agar semua tempat dapat dilewati tanpa mengulang perjalanan. Karena banyaknya kegunaan teori graf dalam kehidupan, maka penelitian mengenai teori graf terus dilakukan. Salah satu bagian yang terus berkembang dalam teori graf adalah dimensi metrik.

Dimensi metrik pertama kali dikenalkan oleh Harary dan Melter pada tahun 1976 [2]. Harary mendefinisikan dimensi metrik melalui himpunan pembeda. Himpunan pembeda adalah himpunan yang menyajikan representasi yang berbeda pada setiap titik yang ada pada graf tersebut. Himpunan pembeda yang memiliki kardinalitas terkecil dari graf $G$ disebut dengan dimensi metrik graf $G$. Penelitian mengenai dimensi metrik telah 
dilakukan antara lain oleh [1] mengenai karakterisasi dimensi metrik pada graf serta [3] mengenai dimensi metrik graf operasi korona.

Pada tahun 2010, [4] mengembangkan konsep dimensi metrik menjadi dimensi metrik lokal. Konsep ini menyatakan setiap dua titik bertetangga di graf $G$ memiliki representasi yang berbeda terhadap suatu himpunan pembeda lokal. Konsep dimensi metrik dikembangkan lebih lanjut oleh [5] yang membangun definisi dimensi metrik ketetanggaan dan [6] yang mendefinisikan dimensi metrik ketetanggaan lokal. Definisi ini dibangun dengan mendefinisikan jarak antara dua titik hanya dengan 0,1 , dan 2 yang secara berurutan menyatakan jarak titik terhadap dirinya sendiri, jarak dua titik yang saling bertetangga, dan jarak dua titik yang tidak bertetangga.

Selanjutnya, [7] mengembangkan konsep dimensi metrik menjadi dimensi metrik kuat. Beberapa penelitian tentang dimensi metrik kuat yang telah dilakukan yaitu dimensi metrik kuat pada graf hasil operasi korona oleh [8], dimensi metrik kuat pada graf hasil operasi akar oleh [9] serta dimensi metrik kuat pada graf hasil operasi kartesian oleh [10].

Dimensi metrik juga dikembangkan pada graf hasil operasi, penelitian mengenai dimensi metrik pada hasil operasi antar graf telah dilakukan antara lain oleh [11] mengenai dimensi metrik dari graf hasil operasi korona. Dua tahun kemudian, [2] meneliti mengenai dimensi metrik graf hasil operasi kali comb. Selanjutnya, [12] mengenai dimensi metrik ketetangaan dan dimensi metrik ketetanggaan lokal graf hasil operasi korona dan graf hasil kali kuat. Pada tahun 2016, [13] melanjutkan penelitian mengenai kekomutatifan operasi korona dan graf hasil operasi kali comb secara dimensi metrik dan secara dimensi metrik lokal.

Berdasarkan uraian di atas, beberapa hasil yang telah ditemukan dari pengembangan konsep dimensi metrik yaitu dimensi metrik lokal, dimensi metrik ketetangaaan, dimensi metrik ketetanggaan lokal, serta dimensi metrik kuat. Diantara beberapa hasil operasi, belum ditemukan penelitian mengenai dimensi metrik kuat lokal hasil operasi kali kartesian. Oleh karena itu pada penelitian ini dibangun konsep dimensi kuat lokal pada graf hasil operasi kartesian.

Definisi 1.1 [14] Misalkan $G_{1}$ dan $G_{2}$ adalah dua buah graf, hasil kali kartesian (cartesian product) $G_{1} \times G_{2}$ adalah graf yang himpunan titiknya $V\left(G_{1}\right) \times V\left(G_{2}\right)$ dan himpunan garisnya dua titik $u_{1} u_{2}$ dan $v_{1} v_{2}$ bertetangga (adjacent) di $G_{1} \times G_{2}$ jika dan hanya jika memenuhi syarat sebagai berikut:

1. $u_{1}=v_{1}$ dan $u_{2} v_{2} \in E\left(G_{2}\right)$ atau

2. $u_{2}=v_{2}$ dan $u_{1} v_{1} \in E\left(G_{1}\right)$

Definisi 1.2 [14] Interval antara titik $u$ dan titik $v$ dinotasikan $I[u, v]$ merupakan himpunan yang beranggotakan semua titik yang termuat dalam lintasan terpendek $u-v$. 
Definisi 1.3 [15] Titik w disebut pembeda kuat lokal pasangan titik yang bertetangga $u, v$ jika terdapat $v \in I[u, w]$ atau terdapat $u \in I[v, w]$.

Definisi 1.4 [15] Misalkan $G$ adalah graf terhubung. Himpunan $W \subseteq V(G)$ dengan $W \neq$ $\varnothing$ disebut himpunan pembeda kuat lokal dari $G$ jika setiap dua titik yang bertetangga pada graf $G$ mempunyai pembeda kuat lokal di $W$. Himpunan pembeda kuat lokal dari $G$ dengan kardinalitas minimal disebut basis metrik kuat lokal graf $G$. Banyaknya titik pada basis metrik kuat lokal graf $G$ disebut dimensi metrik kuat lokal graf $G$, dinotasikan $\operatorname{dim}_{s l}(G)$.

Teorema 1.5 [15] Misalkan $G$ adalah graf terhubung berordo $n \geq 2$, maka berlaku i $\operatorname{dim}_{s l}(G)=1$ jika dan hanya jika $G$ adalah graf bipartit.

ii $\operatorname{dim}_{s l}(G)=n-1$ jika dan hanya jika $G=K_{n}$.

\section{Dimensi Metrik Kuat Lokal Graf Hasil Operasi Kali Kartesian}

Lemma 2.1 Jika $x \in I(u, y)$ dan $y \in I(u, v)$ maka $x \in I(u, v)$.

Bukti : Andaikan $x \notin I(u, v)$, sedangkan $x \in I(u, y)$, maka $y \notin I(u, v)$. Kontradiksi dengan pernyataan $y \in I(u, v)$.

Teorema 2.1 Misalkan $G$ adalah graf bipartit terhubung berordo paling sedikit dua dan $H$ adalah graf terhubung berordo paling sedikit dua, maka

$$
\operatorname{dim}_{s l}(G \times H)=\operatorname{dim}_{s l}(H) .
$$

Bukti : Misalkan $V(G)=\left\{u_{i} \mid i=1,2,3, \ldots, m\right\}$ dengan $m \geq 2, \quad V(H)=\left\{v_{j} \mid j=\right.$ $1,2, \ldots, n\}$ dengan $n \geq 3, \operatorname{dim}_{s l}(H)=k, T=\left\{v_{n_{1}}, v_{n_{2}}, \ldots, v_{n_{k}}\right\}$ basis dari $H$, karena $G$ bipartit $\operatorname{dim}_{s l}(G)=1$ dengan $B=\left\{u_{1}\right\}$ merupakan basis dari $G$. Graf $G$ merupakan graf bipartit sehingga $V(G)$ dapat dipartisi menjadi $U_{1} \neq \varnothing$ dan $U_{2} \neq \varnothing$ sehingga setiap garis di $V(G)$ menghubungkan dua titik di $U_{1}$ dan $U_{2}$. Misalkan $U_{1}=\left\{v_{p_{i}} \in V(G): i=\right.$ $2,3, \ldots, r\}$ dan $U_{2}=\left\{v_{q_{i}} \in V(G): i=2,3, \ldots, s\right\}$ dengan $r+s=m$.

Dipilih $S=\left\{c_{1 n_{1}}, c_{1 n_{2}}, \ldots, c_{1 n_{k}}\right\}$ sehingga $|S|=k=\operatorname{dim}_{s l}(H)$. Diambil sebarang dua titik bertetangga $x, y \in V(G \times H)$. Berdasarkan definisi hasil kali kartesian diperoleh bahwa terdapat dua kemungkinan pasangan titik yaitu

1) Terdapat $j, l \in\{1,2, \ldots, n\}$ dan $i \in\{1,2, \ldots, m\}$ sehingga $x=c_{i j}, y=c_{i l}$, dengan $v_{j} v_{l} \in E(H)$.

2) Terdapat $i, k \in\{1,2, \ldots, m\}$ dan $j \in\{1,2, \ldots, n\}$ sehingga $x=c_{i j}, y=c_{k j}$, dengan $u_{i} u_{k} \in E(G)$.

Akan ditunjukkan bahwa setiap kemungkinan pasangan titik tersebut mempunyai pembeda kuat lokal di $S$. 
Kasus 1. Terdapat $j, l \in\{1,2, \ldots, n\}$ dan $i \in\{1,2, \ldots, m\}$ sehingga $x=c_{i j}, y=c_{i l}$, dengan $v_{j} v_{l} \in E(H)$. Terdapat dua kasus, yaitu $i=1$ dan $i \neq 1$.

Jika $i=1$ akibatnya $v_{j}, v_{l} \in H$ dan $T=\left\{v_{n_{1}}, v_{n_{2}}, \ldots, v_{n_{k}}\right\}$ merupakan basis kuat lokal dari $H$ maka terdapat $c_{1 n_{s}} \in S$ sehingga $c_{1 n_{s}}$ merupakan pembeda kuat lokal dari $x=c_{i j}$ dan $y=c_{i l}$.

Jika $i \neq 1$ akibatnya $v_{j}, v_{l} \in H$ dan $T=\left\{v_{n_{1}}, v_{n_{2}}, \ldots, v_{n_{k}}\right\}$ merupakan basis kuat lokal dari $H$ maka terdapat $v_{n_{s}} \in T$ sehingga $v_{n_{s}}$ merupakan pembeda kuat lokal dari $v_{j}$ dan $v_{l}$. Oleh karena itu, $v_{j} \in I\left(v_{l}, v_{n_{s}}\right)$ atau $v_{l} \in I\left(v_{j}, v_{n_{s}}\right)$. Berdasarkan definisi $G \times$ $H$ diperoleh $c_{i j} \in I\left(c_{i l}, c_{k n_{s}}\right)$ atau $c_{i l} \in I\left(c_{i j}, c_{k n_{s}}\right)$.

$c_{i j} \in I\left(c_{i l}, c_{k n_{s}}\right)$ dan $c_{k n_{s}} \in I\left(c_{i l}, c_{1 n_{s}}\right)$. Berdasarkan Lemma 4.1 dapat disimpulkan $c_{i j} \in I\left(c_{i l}, c_{1 n_{s}}\right)$ atau $c_{i l} \in I\left(c_{i j}, c_{1 n_{s}}\right)$ sehingga $c_{1 n_{s}}$ merupakan pembeda kuat lokal dari dari $x=c_{i j}$ dan $y=c_{i l}$.

Kasus 2. Terdapat $i, k \in\{1,2, \ldots, m\}$ dan $j \in\{1,2, \ldots, n\}$ sehingga $x=c_{i j}, \quad y=c_{k j}$, dengan $u_{i} u_{k} \in E(G)$. Terdapat dua kemungkinan, yaitu $j=1$ dan $j \neq 1$.

1. Jika $j=1$ terdapat dua kemungkinan $x \in S$ atau $x \notin S$

Jika $x \in S$ akibatnya $y \in I(x, y)$ maka $x \in S$ merupakan pembeda kuat lokal dari $x, y$.

Jika $x \notin S$ akibatnya terdapat $c_{1 n_{s}} \in S$ sehingga $x \in I\left(y, c_{1 n_{s}}\right)$, maka $c_{1 n_{S}}$ merupakan pembeda kuat lokal dari $x, y$.

2. Jika $j \neq 1$ akibatnya terdapat $u_{i}, u_{k} \in G$ dan $T=\left\{v_{n_{1}}, v_{n_{2}}, \ldots, v_{n_{k}}\right\}$ merupakan basis kuat lokal dari $H . x=c_{i j}$ dan $y=c_{k j}$, sehinga $c_{i j} \in I\left(c_{k j}, c_{11}\right)$ atau $c_{k j} \in$ $I\left(c_{i j}, c_{11}\right)$. Berdasarkan Lemma 2.1 dapat disimpulkan bahwa $c_{11} \in$ $I\left(c_{k j}, c_{1 n_{s}}\right)$ atau $c_{11} \in I\left(c_{i j}, c_{1 n_{s}}\right)$ sehingga $c_{1 n_{s}}$ merupakan pembeda kuat lokal dari $x=c_{i j}$ dan $y=c_{k j}$.

Selanjutnya, ditunjukkan bahwa $S$ merupakan himpunan pembeda kuat lokal dari graf $G \times H$ dengan kardinalitas minimal. Diambil sebarang $S^{\prime} \subseteq(G \times H)$ dengan $\left|S^{\prime}\right|<|S|$ maka kardinalitas maksimal dari $S^{\prime}$ adalah $|S|-1$. Akibatnya terdapat $b \in 1,2, \ldots|V(G)|$ sehingga maksimal $k-1$ titik di $H_{b}$ yang menjadi elemen di $S^{\prime}$. karena $\operatorname{dim}_{s l}(H)=k$, maka terdapat dua titik yang bertetangga $v_{p}, v_{q} \in V\left(H_{b}\right)$ yang tidak memiliki pembeda kuat lokal di $S^{\prime}$. Akibatnya dua titik yang bertetangga $c_{1 p}, c_{1 q}$ di $G \times H$ tidak memiliki pembeda kuat lokal di $S^{\prime}$.

Berdasarkan uraian di atas diperoleh bahwa $S$ merupakan himpunan pembeda kuat lokal yang memiliki kardinalitas minimal. Sehingga $S$ merupakan basis kuat lokal graf $G \times$ $H$. 
Teorema 2.2 Misalkan $H$ adalah sebarang graf terhubung dengan ordo paling sedikit dua dan $C_{m}$ adalah graf siklus berordo gasal, maka

$$
\operatorname{dim}_{s l}\left(C_{m} \times H\right)=\operatorname{dim}_{s l} C_{m}+\operatorname{dim}_{s l} H-1
$$

Bukti : Misalkan $V\left(C_{m}\right)=\left\{u_{i} \mid i=1,2, \ldots, m\right\}$ dengan $u_{1}=u_{m}, \quad V(H)=\left\{v_{j} \mid j=\right.$ $1,2, \ldots, n\}$ dengan $n \geq 2, \operatorname{dim}_{s l}(H)=k, T=\left\{v_{n_{1}}, v_{n_{2}}, \ldots, v_{n_{k}}\right\}$ basis dari $H$,

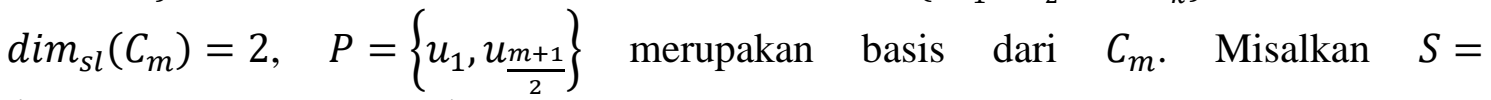
$\left\{c_{1 n_{1}}, c_{1 n_{2}}, \ldots, c_{1 n_{k}}, \frac{c m+1}{2} n_{1}\right\}$ dengan $|S|=k+1$. Diambil sebarang dua titik bertetangga $x, y \in V(G \times H)$. Berdasarkan definisi hasil kali kartesian diperoleh bahwa terdapat dua kemungkinan pasangan titik yaitu

1) Terdapat $j, l \in\{1,2, \ldots, n\}$ dan $i \in\{1,2, \ldots, m\}$ sehingga $x=c_{i j}, y=c_{i l}$, dengan $v_{j} v_{l} \in E(H)$.

2) Terdapat $i, k \in\{1,2, \ldots, m\}$ dan $j \in\{1,2, \ldots, n\}$ sehingga $x=c_{i j}, y=c_{k j}$, dengan $u_{i} u_{k} \in E(G)$.

Akan ditunjukkan bahwa setiap kemungkinan pasangan titik tersebut mempunyai pembeda kuat lokal di $S$.

Kasus 1. Terdapat $j, l \in\{1,2, \ldots, n\}$ dan $i \in\{1,2, \ldots, m\}$ sehingga $x=c_{i j}, y=c_{i l}$, dengan $v_{j} v_{l} \in E(H)$. Terdapat dua kemungkinan, yaitu $i=1$ dan $i \neq 1$.

Jika $i=1$ akibatnya $v_{j}, v_{l} \in H$ dan $T=\left\{v_{n_{1}}, v_{n_{2}}, \ldots, v_{n_{k}}\right\}$ merupakan basis kuat lokal dari $H$ maka terdapat $s \in\{1,2, \ldots, k\}$ sehingga $v_{n_{s}}$ merupakan pembeda kuat lokal dari $v_{j}, v_{l}$. oleh karena itu, $c_{1 n_{s}}$ merupakan pembeda kuat lokal dari $x=c_{i j}$ dan $y=c_{i l}$.

Jika $i \neq 1$ akibtanya $v_{j}, v_{l} \in H$ dan $T=\left\{v_{n_{1}}, v_{n_{2}}, \ldots, v_{n_{k}}\right\}$ merupakan basis kuat lokal dari $H$ maka terdapat $s \in\{1,2, \ldots, k\}$ sehingga $v_{n_{s}}$ merupakan pembeda kuat lokal dari $v_{j}$ dan $v_{l}$. Oleh karena itu, $v_{j} \in I\left(v_{l}, v_{n_{s}}\right)$ atau $v_{l} \in I\left(v_{j}, v_{n_{s}}\right)$. Berdasarkan definisi $G \times$ $H$ diperoleh $c_{i j} \in I\left(c_{i l}, c_{k n_{s}}\right)$ atau $c_{i l} \in I\left(c_{i j}, c_{k n_{s}}\right)$.

$c_{i j} \in I\left(c_{i l}, c_{k n_{s}}\right)$ dan $c_{k n_{s}} \in I\left(c_{i l}, c_{1 n_{s}}\right)$. Berdasarkan Lemma 2.1 dapat disimpulkan bahwa $c_{i j} \in I\left(c_{i l}, c_{1 n_{s}}\right)$ atau $c_{i l} \in I\left(c_{i j}, c_{1 n_{s}}\right)$, sehingga $c_{1 n_{s}}$ merupakan pembeda kuat lokal dari dari $x=c_{i j}$ dan $y=c_{i l}$.

Kasus 2. Terdapat $i, k \in\{1,2, \ldots, m\}$ dan $j \in\{1,2, \ldots, n\}$ sehingga $x=c_{i j}, \quad y=c_{k j}$, dengan $u_{i} u_{k} \in E(G)$. Terdapat dua kasus, yaitu $j=1$ dan $j \neq 1$.

1. Jika $j=1$ terdapat dua kemungkinan $x \in S$ atau $x \notin S$

Jika $x \in S$ akibatnya $y \in I(x, y)$ maka $x \in S$ merupakan pembeda kuat lokal dari $x, y$. 
Jika $x \notin S$ akibatnya terdapat $c_{1 n_{S}} \in S$ sehingga $x \in I\left(y, c_{1 n_{S}}\right)$, maka $c_{1 n_{S}}$ merupakan pembeda kuat lokal dari $x, y$, atau terdapat $\frac{c m+1}{2} n_{1} \in S$ sehingga $x \in$ $I\left(y, \frac{c m+1}{2} n_{1}\right)$ maka $\frac{c m+1}{2} n_{1}$ merupakan pembeda kuat lokal dari $x, y$.

2. Jika $j \neq 1$. Terdapat $u_{i}, u_{k} \in G$ dan $T=\left\{v_{n_{1}}, v_{n_{2}}, \ldots, v_{n_{k}}\right\}$ merupakan basis kuat lokal dari $H$ maka terdapat $s \in\{1,2, \ldots, k\}$ sehingga $v_{n_{s}}$ merupakan pembeda kuat lokal dari $v_{j}$ dan $v_{l}$. Oleh karena itu, $v_{j} \in I\left(v_{l}, v_{n_{s}}\right)$ atau $v_{l} \in I\left(v_{j}, v_{n_{s}}\right)$. Berdasarkan definisi $G \times H$ dan $x=c_{i j} y=c_{k j}$, maka $c_{i j} \in I\left(c_{k j}, c_{1 n_{s}}\right)$ atau $c_{k j} \in I\left(c_{i j}, c_{1 n_{s}}\right)$. Oleh sebab itu, $c_{1 n_{s}}$ merupakan pembeda kuat lokal dari $x=c_{i j}$ dan $y=c_{k j}$.

Selanjutnya, ditunjukkan bahwa $S$ merupakan himpunan pembeda kuat lokal dari graf $G \times H$ dengan kardinalitas minimal. Diambil sebarang $S^{\prime} \subseteq(G \times H)$ dengan $\left|S^{\prime}\right|<|S|$ maka kardinalitas maksimal dari $S^{\prime}$ adalah $|S|-1$. Tanpa Mengurangi keumuman bukti, akibatnya terdapat $a \in 1,2, \ldots|V(H)|$ sehingga maksimal satu titik di $G_{a}$ yang menjadi elemen di $S^{\prime}$. Karena $\operatorname{dim}_{s l}(G)=2$, akibatnya terdapat dua titik $u_{p}, u_{q} \in V\left(G_{a}\right)$ yang tidak memiliki pembeda kuat lokal di $S^{\prime}$. Akibatnya terdapat dua titik $c_{p 1}, c_{q 1} \operatorname{di} G \times H$ yang tidak memiliki pembeda kuat lokal di $S^{\prime}$.

Berdasarkan uraian di atas diperoleh bahwa $S$ merupakan himpunan pembeda kuat lokal yang memiliki kardinalitas minimal. Sehingga $S$ merupakan basis kuat lokal graf $C_{m} \times$ $H$.

Teorema 2.3 Misalkan $K_{m}$ adalah graf lengkap berordo m dan $H$ adalah graf terhubung berordo lebih dari dua, maka

$$
\operatorname{dim}_{s l}\left(K_{m} \times H\right)=\operatorname{dim}_{s l} K_{m}+\operatorname{dim}_{s l} H-1
$$

Bukti : Misalkan $V\left(K_{m}\right)=\left\{u_{i} \mid i=1,2, \ldots, m\right\}, \quad V(H)=\left\{v_{j} \mid j=1,2, \ldots, n\right\}$ dengan $n \geq 2, \operatorname{dim}_{s l}(H)=k, T=\left\{v_{n_{1}}, v_{n_{2}}, \ldots, v_{n_{k}}\right\}$ basis dari $H, \operatorname{dim}_{s l}\left(K_{m}\right)=m-1, N=$ $\left\{u_{1}, u_{2}, \ldots, u_{m-1}\right\}$ merupakan basis kuat lokal dari $K_{m}$. Misalkan $S=$ $\left\{c_{1 n_{1}}, c_{1 n_{2}}, \ldots, c_{1 n_{k}}, c_{2 n_{1}}, c_{3 n_{1}}, \ldots, c_{m-1 n_{1}}\right\} .|S|=m+k-2$. Diambil sebarang dua titik bertetangga $x, y \in V(G \times H)$. Berdasarkan definisi hasil kali kartesian diperoleh bahwa terdapat dua kemungkinan pasangan titik, yaitu

1. Terdapat $j, l \in\{1,2, \ldots, n\}$ dan $i \in\{1,2, \ldots, m\}$ sehingga $x=c_{i j}, y=c_{i l}$, dan $v_{j} v_{l} \in E(H)$.

2. Terdapat $i, k \in\{1,2, \ldots, m\}$ dan $j \in\{1,2, \ldots, n\}$ sehingga $x=c_{i j}, \quad y=c_{k j}$, dan $u_{i} u_{k} \in E(G)$.

Akan ditunjukkan bahwa setiap kemungkinan pasangan titik tersebut mempunyai pembeda kuat lokal di $S$.

Kasus 1. Terdapat $j, l \in\{1,2, \ldots, n\}$ dan $i \in\{1,2, \ldots, m\}$ sehingga $x=c_{i j}, y=c_{i l}$, dengan $v_{j} v_{l} \in E(H)$. Terdapat dua kasus, yaitu $i=1$ dan $i \neq 1$. 
Jika $i=1$ akibatnya $v_{j}, v_{l} \in H$ dan $T=\left\{v_{n_{1}}, v_{n_{2}}, \ldots, v_{n_{k}}\right\}$ merupakan basis kuat lokal dari $H$ maka terdapat $s \in\{1,2, \ldots, k\}$ sehingga $v_{n_{s}}$ merupakan pembeda kuat lokal dari $v_{j}, v_{l}$. Oleh karena itu, $c_{1 n_{s}}$ merupakan pembeda kuat lokal dari $x=c_{i j}$ dan $y=c_{i l}$.

Jika $i \neq 1$ akibatnya $v_{j}, v_{l} \in H$ dan $T=\left\{v_{n_{1}}, v_{n_{2}}, \ldots, v_{n_{k}}\right\}$ merupakan basis kuat lokal dari $H$ maka terdapat $s \in\{1,2, \ldots, k\}$ sehingga $v_{n_{s}}$ merupakan pembeda kuat lokal dari $v_{j}$ dan $v_{l}$. Oleh karena itu, $v_{j} \in I\left(v_{l}, v_{n_{s}}\right)$ atau $v_{l} \in I\left(v_{j}, v_{n_{s}}\right)$. Berdasarkan definisi $G \times$ $H$ diperoleh $c_{i j} \in I\left(c_{i l}, c_{k n_{s}}\right)$ atau $c_{i l} \in I\left(c_{i j}, c_{k n_{s}}\right)$.

$c_{i j} \in I\left(c_{i l}, c_{k n_{s}}\right)$ dan $c_{k n_{s}} \in I\left(c_{i l}, c_{1 n_{s}}\right)$. Berdasarkan Lemma 2.1 dapat disimpulkan bahwa $c_{i j} \in I\left(c_{i l}, c_{1 n_{s}}\right)$ atau $c_{i l} \in I\left(c_{i j}, c_{1 n_{s}}\right)$ sehingga $c_{1 n_{s}}$ merupakan pembeda kuat lokal dari dari $x=c_{i j}$ dan $y=c_{i l}$.

Kasus 2. Terdapat $i, k \in\{1,2, \ldots, m\}$ dan $j \in\{1,2, \ldots, n\}$ sehingga $x=c_{i j}, y=c_{k j}$, dan $u_{i} u_{k} \in E(G)$. Terdapat dua kasus, yaitu $j=1$ dan $j \neq 1$.

1. Jika $j=1$ akibatnya $y \in I(x, y)$ maka $x \in S$ merupakan pembeda kuat lokal dari $x, y$.

2. Jika $j \neq 1$ akibatnya $u_{i}, u_{k} \in G$ dan $T=\left\{v_{n_{1}}, v_{n_{2}}, \ldots, v_{n_{k}}\right\}$ merupakan basis kuat lokal dari $H$ maka terdapat $s \in\{1,2, \ldots, k\}$ sehingga $v_{n_{s}}$ merupakan pembeda kuat lokal dari $v_{j}$ dan $v_{l}$. Oleh karena itu, $v_{j} \in I\left(v_{l}, v_{n_{s}}\right)$ atau $v_{l} \in I\left(v_{j}, v_{n_{s}}\right)$. Berdasarkan definisi $G \times H$ dan $x=c_{i j} y=c_{k j}$, maka $c_{i j} \in I\left(c_{k j}, c_{1 n_{s}}\right)$ atau $c_{k j} \in I\left(c_{i j}, c_{1 n_{s}}\right)$. Oleh sebab itu, $c_{1 n_{s}}$ merupakan pembeda kuat lokal dari $x=$ $c_{i j}$ dan $y=c_{k j}$.

Selanjutnya, ditunjukkan bahwa $S$ merupakan himpunan pembeda kuat lokal dari graf $K_{m} \times H$ dengan kardinalitas minimal. Diambil sebarang $S^{\prime} \subseteq\left(K_{m} \times H\right)$ dengan $\left|S^{\prime}\right|<$ $|S|$ maka kardinalitas maksimal dari $S^{\prime}$ adalah $|S|-1$. Tanpa Mengurangi keumuman bukti, akibatnya terdapat $b \in 1,2, \ldots\left|V\left(K_{m}\right)\right|$ sehingga maksimal $k-1$ titik di $H_{b}$ yang menjadi elemen di $S^{\prime}$. Karena $\operatorname{dim}_{s l}(H)=k$, akibatnya terdapat dua titik $v_{p}, v_{q}$ di $H_{b}$ yang tidak memiliki pembeda kuat lokal di $S^{\prime}$. Sehingga terdapat dua titik $c_{1 p}, c_{1 q}$ di $G \times$ $H$ yang tidak memiliki pembeda kuat lokal di $S^{\prime}$.

Berdasarkan uraian di atas diperoleh bahwa $S$ merupakan himpunan pembeda kuat lokal yang memiliki kardinalitas minimal. Sehingga $S$ merupakan basis kuat lokal graf $K_{m} \times$ $H$.

Berdasarkan Teorema 2.1, Teorema 2.2, dan Teorema 2.3 diperoleh

Teorema 2.4 Misalkan $G$ adalah graf terhubung berordo paling sedikit dua dan graf $H$ adalah graf terhubung berordo paling sedikit dua, maka

$$
\operatorname{dim}_{s l}(G \times H)=\operatorname{dim}_{s l} G+\operatorname{dim}_{s l} H-1
$$

Bukti : Misalkan $V(G)=\left\{u_{i} \mid i=1,2, \ldots, m\right\} \quad V(H)=\left\{v_{j} \mid j=1,2, \ldots, n\right\}$ dengan $n \geq$ $2, \operatorname{dim}_{s l}(H)=k, \quad T=\left\{v_{n_{1}}, v_{n_{2}}, \ldots, v_{n_{k}}\right\}$ basis dari $H, \operatorname{dim}_{s l}(G)=t, \quad W=$ 
$\left\{u_{x_{1}}, u_{x_{2}}, \ldots, u_{x_{t}}\right\}$ merupakan basis dari $G$. Misalkan $S=$ $\left\{c_{1 n_{1}}, c_{1 n_{2}}, \ldots, c_{1 n_{k}}, c_{2 n_{1}}, c_{3 n_{1}}, \ldots, c_{t-1 n_{1}}\right\}$. Diambil sebarang dua titik bertetangga $x, y \in$ $V(G \times H)$. Berdasarkan definisi hasil kali kartesian diperoleh bahwa terdapat dua kemungkinan pasangan titik yaitu

1. Terdapat $j, l \in\{1,2, \ldots, n\}$ dan $i \in\{1,2, \ldots, m\}$ sehingga $x=c_{i j}, y=c_{i l}$, dengan $v_{j} v_{l} \in E(H)$.

2. Terdapat $i, k \in\{1,2, \ldots, m\}$ dan $j \in\{1,2, \ldots, n\}$ sehingga $x=c_{i j}, \quad y=c_{k j}$, dengan $u_{i} u_{k} \in E(G)$.

Akan ditunjukkan bahwa setiap kemungkinan pasangan titik tersebut mempunyai pembeda kuat lokal di $S$.

Kasus 1. Terdapat $j, l \in\{1,2, \ldots, n\}$ dan $i \in\{1,2, \ldots, m\}$ sehingga $x=c_{i j}, y=c_{i l}$, dengan $v_{j} v_{l} \in E(H)$. Terdapat dua kasus, yaitu $i=1$ dan $i \neq 1$.

Jika $i=1$ akibatnya $v_{j}, v_{l} \in H$ dan $T=\left\{v_{n_{1}}, v_{n_{2}}, \ldots, v_{n_{k}}\right\}$ merupakan basis kuat lokal dari $H$ maka terdapat $s \in\{1,2, \ldots, k\}$ sehingga $v_{n_{s}}$ merupakan pembeda kuat lokal dari $v_{j}, v_{l}$. oleh karena itu, $c_{1 n_{s}}$ merupakan pembeda kuat lokal dari $x=c_{i j}$ dan $y=c_{i l}$.

Jika $i \neq 1$ akibatnya $v_{j}, v_{l} \in H$ dan $T=\left\{v_{n_{1}}, v_{n_{2}}, \ldots, v_{n_{k}}\right\}$ merupakan basis kuat lokal dari $H$ maka terdapat $s \in\{1,2, \ldots, k\}$ sehingga $v_{n_{s}}$ merupakan pembeda kuat lokal dari $v_{j}$ dan $v_{l}$. Oleh karena itu, $v_{j} \in I\left(v_{l}, v_{n_{s}}\right)$ atau $v_{l} \in I\left(v_{j}, v_{n_{s}}\right)$. Berdasarkan definisi $G \times$ $H$ diperoleh $c_{i j} \in I\left(c_{i l}, c_{k n_{s}}\right)$ atau $c_{i l} \in I\left(c_{i j}, c_{k n_{s}}\right)$.

$c_{i j} \in I\left(c_{i l}, c_{k n_{s}}\right)$ dan $c_{k n_{s}} \in I\left(c_{i l}, c_{1 n_{s}}\right)$. Berdasarkan Lemma 2.1 dapat disimpulkan bahwa $c_{i j} \in I\left(c_{i l}, c_{1 n_{s}}\right)$ atau $c_{i l} \in I\left(c_{i j}, c_{1 n_{s}}\right)$ sehingga $c_{1 n_{s}}$ merupakan pembeda kuat lokal dari dari $x=c_{i j}$ dan $y=c_{i l}$.

Kasus 2. Terdapat $i, k \in\{1,2, \ldots, m\}$ dan $j \in\{1,2, \ldots, n\}$ sehingga $x=c_{i j}, y=c_{k j}$, dan $u_{i} u_{k} \in E(G)$. terdapat dua kasus, yaitu $j=1$ dan $j \neq 1$.

1. Jika $j=1$ terdapat dua kemungkinan $x \in S$ atau $x \notin S$

Jika $x \in S$, akibatnya $y \in I(x, y)$ maka $x \in S$ merupakan pembeda kuat lokal dari $x, y$.

Jika $x \notin S$, akibatnya terdapat $c_{1 n_{s}} \in S$ sehingga $x \in I\left(y, c_{1 n_{s}}\right)$, maka $c_{1 n_{s}}$ merupakan pembeda kuat lokal dari $x, y$, atau terdapat $c_{m n_{1}} \in S$ sehingga $x \in$ $I\left(y, c_{t n_{1}}\right)$ maka $c_{t n_{1}}$ merupakan pembeda kuat lokal dari $x, y$.

2. Jika $j \neq 1$ akibatnya $u_{i}, u_{k} \in V(G)$ dan $W=\left\{u_{x_{1}}, u_{x_{2}}, \ldots, u_{x_{t}}\right\}$ merupakan basis dari $G$ maka terdapat $s \in\{1,2, \ldots, t\}$ sehingga $u_{m_{s}}$ merupakan pembeda kuat lokal dari $u_{i}$ dan $u_{k}$. Oleh karena itu, $u_{i} \in I\left(u_{k}, u_{t_{s}}\right)$ atau $u_{k} \in I\left(u_{i}, u_{t_{s}}\right)$. Berdasarkan definisi $G \times H$ diperoleh bahwa $c_{i j} \in I\left(c_{k j}, c_{1 n_{s}}\right)$ atau $c_{k j} \in$ 
$I\left(c_{i j}, c_{1 n_{s}}\right)$. Oleh sebab itu, $c_{1 n_{s}}$ merupakan pembeda kuat lokal dari $x=c_{i j}$ dan $y=c_{k j}$.

Selanjutnya, ditunjukkan bahwa $S$ merupakan himpunan pembeda kuat lokal dari graf $G \times H$ dengan kardinalitas minimal. Diambil sebarang $S^{\prime} \subseteq(G \times H)$ dengan $\left|S^{\prime}\right|<|S|$ maka kardinalitas maksimal dari $S^{\prime}$ adalah $|S|-1$. Akibatnya terdapat $b \in 1,2, \ldots|V(G)|$ sehingga maksimal $k-1$ titik di $H_{b}$ yang menjadi elemen di $S^{\prime}$.

Akibatnya terdapat dua titik yang bertetangga $v_{p}, v_{q} \in V\left(H_{b}\right)$ yang tidak memiliki pembeda kuat lokal di $S^{\prime}$. Akibatnya dua titik yang bertetangga $c_{1 p}, c_{1 q}$ di $G \times H$ tidak memiliki pembeda kuat lokal di $S^{\prime}$.

Berdasarkan uraian di atas diperoleh bahwa $S$ merupakan himpunan pembeda kuat lokal yang memiliki kardinalitas minimal. Sehingga $S$ merupakan basis kuat lokal graf $G \times$ $H$.

\section{Kesimpulan}

Dalam menentukan dimensi metrik kuat lokal graf hasil kartesian dari graf umum, terlebih dahulu ditentukan dimensi metrik graf umum dan graf khusus, sehingga diperoleh dimensi metrik kuat lokal graf $G \times H$ umum yaitu jumlah dimensi metrik kuat lokal graf $G$ dan $H-1$.

\section{Saran}

Berdasarkan hasil pembahasan pada bab sebelumnya, penelitian ini dapat dikembangkan untuk menentukan dimensi metrik kuat lokal pada graf hasil operasi kartesian tingkat $\mathrm{k}$, operasi k-comb, dan sebagainya.

\section{Daftar Pustaka}

[1] Chartrand, G. and Lesniak, L., 2000, Graphs and Digraphs, Third Edition,Chapman \& Hall/CRC, Florida.

[2] Saputro, S.W., Mardiana, N., and Purwasih, I.A., 2013, The Metrik Dimension of Comb Product Graphs, Graph Theory Conference in honor of Egwa's 60th birthday.

[3] Iswandi, H., Simanjutak, and Baskoro. 2011. On The Metric Dimension of Corona Product Graphs. Prosiding Seminar Matematika dan Pendidikan Matematik 1 : 196-201.

[4] Okamoto, F., Crosse, L., Phinezy, B., and Kalamazoo, 2010, The Lokal Metrik Dimension of a Graph, Mathematica Bohemica, 135:3, 239-255.

[5] Jannesari, M., and Omoomi, B., 2012, The Metrik Dimension of the Lexicographic Product of Graphs, Discrete Mathematics, 312, 3349-3356. 
[6] Rodriguez-Valazquez, J.A., Fernau, H., 2013, On The (adjacency) Metrik Dimension of Corona Product Graphs and Their Lokal Variants, Combinatorial and Computational Results, Arxiv 1309.2275.vl (Math Co).

[7] Sebo, A. and Tannier, E., 2004, On Metrik Generator of Graphs, Mathematics of Operator Research, 29:2, 383-393.

[8] Kuziak, D., Yero, I.G., and Rodriguez-Valazquez, J.A., 2013a, On The Strong Metrik Dimension of Corona Product Graphs and Join Graphs, Discrete Appl. Math., 161, 1022-1027.

[9] Kuziak, D., Yero, I.G., and Rodriguez-Valazquez, J.A., 2013b, Strong Metrik Dimension of Rooted Product Graphs, International Journal of Computer Mathematics., 93:8, 1265-1280.

[10] Rodriguez-Valazquez, J.A., Yero, I.G., Kuziak, D., Oellermann, O.R., 2014, On the Strong Metrik Dimension of Cartesian and Direct Product Graphs, Dicrete Mathematics, 335, 8-19.

[11] Yero, I.G., Kuziak, D., and Rodriguez-Valazquez, J.A., 2011, On The Metrik Dimension of Corona Product Graphs, Computers and Mathematics with Apllications, 68, 2793-2798.

[12] Rodriguez-Valazquez, J.A., A. Gabriel, Barragan-Ramirez, and Gomez, C.G., 2016, On The Lokal Metrik Dimension of Corona Product Graphs, Bulletin of the Malaysian Mathematical Sciences Society, 39, 157-173.

[13] Susilowati, L., Slamin, Utoyo, M. I., and Estuningsih, N. 2016. The Similarity of Metric Dimension and Local Metric Dimension of Rooted Product Graph. Far East Journal of Mathematical Sciences (FJMS) 97: 841-856.

[14] Oellermann, O.R, Peters-Fransen, J., 2007, The Strong Metrik Dimension of Graphs and Digraphs, Discrete Appl. Math., 155, 356-364.

[15] Susilowati, L., Rosfiana, A., Purwati, U.D., 2018, The Local Metric Dimension and The Strong Metric Dimension of Corona Product Graph Order-k Discrete Applied Mathematics, Manuscript Number DA9697, submitted. 